\title{
Growth and Development of Cherry Tomato Seedlings Grown under Various Combined Ratios of Red to Blue LED Lights and Fruit Yield and Quality after Transplanting
}

\author{
Ki-Ho Son ${ }^{1,2}$, Eun-Young Kim ${ }^{3}$, and Myung-Min $\mathrm{Oh}^{1,2 *}$ \\ ${ }^{1}$ Division of Animal, Horticultural and Food Sciences, Chungbuk National University, Cheongju 28644, Republic of Korea \\ ${ }^{2}$ Brain Korea 21 Center for Bio-Resource Development, Chungbuk National University, Cheongju 28644, Republic of Korea \\ ${ }^{3}$ Yeongdong Country Agricultural Technology \& Extension Center, Yeongdong 29153, Republic of Korea
}

\begin{abstract}
Red and blue lights are effective wavelengths for photosynthesis in plants. In this study, we determined the effects of various combined ratios of red to blue LEDs on the quality of cherry tomato seedlings prior to transplantation, and their subsequent effects on the yield and quality of tomato fruits after transplanting. Two-week-old cherry tomato seedlings (Solanum lycopersicum cv. 'Cuty') were cultivated under various combined ratios of red (R; peak wavelength $655 \mathrm{~nm}$ ) to blue $(\mathrm{B} ; 456 \mathrm{~nm})$ LEDs [red:blue = 41:59 (59B), 53:47 (47B), 65:35 (35B), 74:26 (26B), 87:13 (13B), or 100:0 (0B)] and fluorescent lamps and raised for 27 days. The cherry tomato seedlings were subsequently transplanted into a venlo-type greenhouse and cultivated for 75 days. At the seedling stage, the shoot fresh weight of seedlings in all RB combined treatments, except $0 \mathrm{~B}$ and $59 \mathrm{~B}$, was higher than that of the control after 27 days of LED treatment. Shoot dry weight and leaf area also showed trends similar to that of shoot fresh weight. The stem length was significantly higher in 13B, 26B, and 35B treatments compared with the control and other treatments. In particular, the stem length of 26B plants was approximately 3.2 times longer than that of 59B plants. At 37 days after transplanting, the number of nodes was significantly higher in $26 \mathrm{~B}$ and $47 \mathrm{~B}$ plants, and the plant height of 26B plants was significantly higher than that of control and 59B plants. Total fruit yield in 26B plants, which was the highest, was approximately 1.6 and 1.8 times higher than that in control and 59B plants, respectively. Thus, the results of this study indicate that various combined ratios of red to blue LEDs directly affected to the growth of cherry tomato seedlings and may also affect parameters of reproductive growth such as fruit yield after transplantation.
\end{abstract}

Additional key words : fruit quality, number of nodes, plant height, stem elongation, total fruit yield

\section{Introduction}

Tomato (Solanum lycopersicum L.), a photophilic plant, can be cultivated in greenhouses all year around and is one of the seventh most produced crops in the world (Fan et al., 2013). As the vegetative and reproductive growth of tomato plants progress simultaneously from the seedling stage, the cultural practices undertaken at this stage are crucial for the production of high-quality cherry tomato fruit, as well as fruit yield (Buwalda et al., 2006). In particular, manipulation of environmental conditions during the seedling stage is an essential technique for improving the yield and fruit quality of tomato plants.

A closed-type plant production system has been used in the crop production industry. This system has the advan-

\footnotetext{
*Corresponding author: moh@cbnu.ac.kr

Received November 01, 2017; Revised December 22, 2017;

Accepted December 29, 2017
}

tage of improving crop yield and quality by controlling crop growing environmental factors such as light, $\mathrm{CO}_{2}$ concentration, temperature, humidity, and nutrient components within facilities, regardless of the external environment (Kozai, 2013). However, it is difficult to make a profit using a commercial closed-type plant production system due to the high initial investment and management costs (power consumption) (Um et al., 2010). To date, most of the studies related to closed-type plant production systems have focused on leafy vegetables.

Light quality plays an important role as a signal for photosynthesis, photomorphogenesis, and other plant responses (Wang et al., 2009). It is well known that over $90 \%$ of red and blue wavelengths in the visible spectrum are absorbed by leaves for photosynthesis (Terashima et al., 2009), because chlorophyll $a$ and $b$, which are required for the absorption and transfer of light energy, efficiently absorb both the red (maximum absorption at 663 and $642 \mathrm{~nm}$ ) and blue (maximum absorption at 430 and $453 \mathrm{~nm}$ ) ranges of 
visible light (Hopkins and Huner, 2004). Thus, blue or red light may strongly affect plant growth and development (McNellis and Deng, 1995). Recently, illumination derived from the combination of red and blue light-emitting diodes (LEDs) has been used in research areas as well as in the commercial horticulture industry (Rehman et al., 2017). Previous studies related to the use of combined red and blue LEDs have examined the responses of various plants, such as pepper, wheat, spinach, radish, lettuce, and rice (Brown et al., 1995; Goins et al., 1997; Matsuda et al., 2004; Son and Oh, 2013; Yorio et al., 2001). Related studies have been conducted on the effect of combined red and blue LEDs on the stem elongation and flowering (Nanya et al., 2012), growth and leaf development (Fan et al., 2013), carbohydrate accumulation and sucrose metabolism responses ( $\mathrm{Li}$ et al., 2017), and physiological responses (Hernández and Kubota, 2016) of tomato seedlings. How- ever, most of these studies have compared limited ratios of red and blue LEDs or have been conducted with young tomato plants (seedlings), and have not examined responses after transplantation. Thus, in this study, we aimed to determine the effect of various combined ratios of red to blue LEDs on the growth and development of cherry tomato seedlings and to analyze the effects of different quality tomato seedlings on fruit yield and quality after transplanting.

\section{Materials and Methods}

\section{Light-emitting diode (LED) treatments}

The red (R; Bright LED Electronics Co., Seoul, Korea) and blue (B; Itswell Co., Incheon, Korea) LEDs used to cultivate cherry tomato seedlings had peak wavelengths at $655 \mathrm{~nm}$ and $456 \mathrm{~nm}$, respectively. Six different light treat-

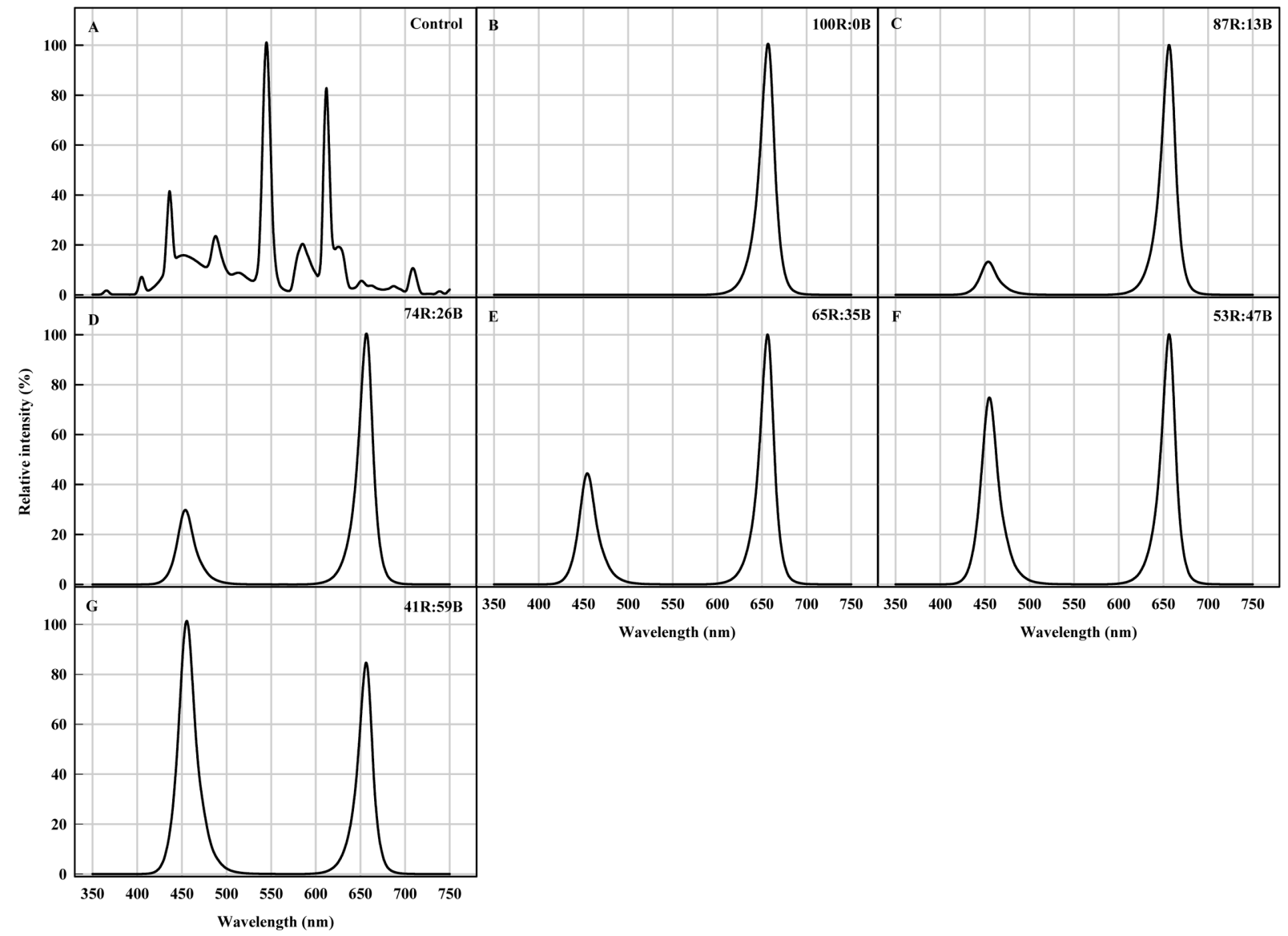

Fig. 1. Relative spectral distribution of various combinations of red and blue light-emitting diodes (LEDs) used in this study. (A) control (fluorescent lamp + high pressure sodium lamp), (B), red:blue $=100: 0,(\mathrm{C})$ red:blue $=87: 13$, (D) red:blue $=74: 26$, (E) red:blue $=65: 35$, (F) red:blue $=53: 47,(\mathrm{G})$ red:blue $=41: 59$. Photosynthetic photon flux density was about $198.6 \pm 5 \mu \mathrm{mol} \cdot \mathrm{m}^{-2} \cdot \mathrm{s}^{-1}$ in each treatment. Spectral scans were recorded at the top of the plant canopies and averaged at 5 points a center and 4 edges of each tray. 
ments were established by combining $\mathrm{R}$ and $\mathrm{B}$ LEDs as follows: R:B = 41:59 (59B), 53:47 (47B), 65:35 (35B), $74: 26$ (26B), 87:13 (13B), and 100:0 (0B) which was expressed based on photosynthetic photon flux density (PPFD). The light spectra of fluorescent lamps with highpressure lamps (FL + HPS; control treatment) and the LED treatments were measured using a portable spectroradiometer (LI-1800; Li-Cor, Lincoln, NE, USA) at 2-nm intervals in the range of 300 to $1000 \mathrm{~nm}$, and presented as relative light intensity (\%) (Fig. 1).

\section{Plant materials and growing conditions}

\subsection{Pre-transplantation}

Cherry tomato seeds (Solanum lycopersicum L. cv. Cuty) were sown in two 50-cell plug trays containing growing medium (Myung-Mun, Dong-Bu, Seoul, Korea), and then grown under the following conditions in a growth chamber for 18 days: air temperature $24^{\circ} \mathrm{C}$, relative humidity $60 \%$ $70 \%$, PPFD of FL with HPS $105.3 \pm 5 \mu \mathrm{mol} \cdot \mathrm{m}^{-2} \cdot \mathrm{s}^{-1}$, and photoperiod $12 \mathrm{~h}$. Tomato seedlings (64 seedlings per treatment) were transferred to growth chambers (DS-51GLP; Dasol Scientific, Hwaseong, Korea) equipped with LED lighting sources and cultivated for 27 days. Growth conditions for all treatments were maintained at an air temperature of $25 / 20^{\circ} \mathrm{C}$ (day/night), photoperiod of $12 \mathrm{~h}$, and PPFD of $198.6 \pm 5 \mu \mathrm{mol} \cdot \mathrm{m}^{-2} \cdot \mathrm{s}^{-1}$ at the canopy height of the seedlings. The distance between each lighting source and apical meristems was maintained at $20 \mathrm{~cm}$ during the growth period. To reduce any effects of light distribution, systematical rotation was performed daily. The tomato seedlings were watered with $2 \mathrm{~L}$ of Yamazaki's nutrient solution $(\mathrm{pH}$ 5.9, EC $1.1 \mathrm{dS} \cdot \mathrm{m}^{-1}, \mathrm{~N}: \mathrm{P}: \mathrm{K}=20.3: 18.2: 24.9$ ) in the container once a week.

\subsection{Post-transplantation}

To verify the effect of cherry tomato seedlings grown under various combined red and blue LEDs on tomato yield, the seedlings were transplanted into a venlo-type greenhouse located in Gimje, South Korea, and cultivated there for 75 days. Twelve cherry tomato seedlings from each LED treatment were transplanted into three bags containing cocopeat substrate $(90 \times 15 \times 12 \mathrm{~cm}$, Cocomix, Korea). The cultural practice for cherry tomato plants followed that recommended by the Rural Development Administration (RDA) farming standard handbook (RDA, 2001). Removal of lateral branches was carried out once a week, and fertilization by pollen was mediated via bumblebees (Woori bee, Bombus terrestris; Dongbu Farm Ceres Co., Seoul, Korea). The average temperature, relative humidity, and daily integrated radiation were measured using the program of a multi-variable controlling environment (SH-3000; Shinhan A-tec Co., Changwon, Korea). The average temperature, relative humidity, and daily integrated radiation were $27.3 / 23.6^{\circ} \mathrm{C}$ (day/night), $76 \%$, and $2252.03 \mathrm{MJ}$ day $^{-1}$, respectively. The tomato plants were watered daily with $500 \mathrm{~mL}$ of Yamazaki's nutrient solution ( $\left.\mathrm{pH} 5.8, \mathrm{EC} 1.8 \mathrm{dS} \cdot \mathrm{m}^{-1}\right)$ controlled by a timer.

\section{Growth characteristics}

\subsection{Pre-transplantation}

To determine the growth characteristics of cherry tomato seedlings raised under various combined red and blue LEDs, the fresh weights of shoots and roots were measured using an electronic balance (SI-234; Denver Instrument, USA) after 27 days of LED treatment. The dry weights of shoots and roots, dried in an oven (VS1202D3; Vision Science, Daejeon, Korea) at $70^{\circ} \mathrm{C}$ for $72 \mathrm{~h}$, were measured using the electronic balance. A portable leaf area meter (Li-3000A; Li-Cor, Lincoln, USA) was used for measuring leaf area. Specific leaf weight (SLW), an index of leaf thickness, was calculated by dividing the shoot dry weight $(\mathrm{mg})$ by leaf area. Relative chlorophyll content of the third leaf from the apical meristem was obtained using a portable chlorophyll meter (SPAD-502; Minolta, Japan). The number of nodes and internode length between the second and third branches were also measured. Stem length and stem diameter at proximal to the surface of cocopeat substrate were measured using a ruler and digital Vernier calipers, respectively.

\subsection{Post-transplantation}

Measurement of the growth characteristics of tomato plants was carried out at 37 days after transplanting (DAT) when the plants had four or five fruit clusters. The measurement parameters and methods were the same as those used prior to transplantation. The stem diameter at the eleventh node was measured using Vernier calipers. SPAD values were obtained for the fourth branch leaves from the apical meristem.

\section{Fruit yield and quality}

The tomato fruit was harvested twice at 68 and 75 DAT. 
Total fruit yield, fruit weight and size, soluble solids content, and total acidity were measured at the time of harvest. The soluble solids content of fruits was measured using a portable digital brix refractometer (Poket PAL-1; Atago, Japan) at 68 DAT and the total acidity of fruits was measured using the phenolphthalein method (Oh, 2012) at 75 DAT.

\section{Statistical analysis}

To determine the effect of combined red and blue LED ratios (before transplanting), four cherry tomato seedlings per treatment were used to determine all growth characteristics and chlorophyll contents (SPAD value). To analyze the growth characteristics and total fruit yield of cherry tomato plants after transplanting, three replicates were used for each treatment. Fruit characteristics such as fruit weight and size, soluble solids content, and total acidity were determined by using six fruits per plant. ANOVA was performed using the SAS 9.2 statistical analysis system (SAS Institute, USA). Duncan's multiple range test was used to compare the means among treatments.

\section{Results and Discussion}

\section{Growth characteristics}

\subsection{Pre-transplantation}

Cherry tomato seedlings raised under various lighting conditions using combined red and blue LEDs showed differences in fresh and dry weights, leaf area, SLW, and SPAD value (Table 1). With the exception of the $0 \mathrm{~B}$ and
59B treatments, the LED treatments promoted significantly higher shoot fresh weights than the control, with a gradual increase in weight being observed with an increasing red LED ratio. Treatment $13 \mathrm{~B}$ showed the highest value, which was approximately twice that of the control. The shoot dry weight results were similar to those of fresh weight; however, the weights of the $26 \mathrm{~B}, 35 \mathrm{~B}$ and $47 \mathrm{~B}$ treated plants were significantly higher than that of the control. With regards to root fresh weight, $0 \mathrm{~B}, 13 \mathrm{~B}$, and $35 \mathrm{~B}$ treated plants showed significantly higher values than the control and the plants subjected to the other LED treatments. Root dry weight showed a similar trend to that of root fresh weight. The results for leaf area were similar to those obtained for shoot fresh weight, where LED treatments yielded significantly higher values than the control, with the exceptions of $0 \mathrm{~B}$ and 59B. For SLW, which is representative of leaf thickness, the $0 \mathrm{~B}$ treatment showed the significantly highest value. SPAD values, indicating chlorophyll content, were higher in treatments with a high ratio of blue light such as $26 \mathrm{~B}, 35 \mathrm{~B}$, and $47 \mathrm{~B}$, whereas there was no significant difference between the $59 \mathrm{~B}$ and control treatments, which showed the lowest values.

Supplementation or mixture of blue LEDs with red LEDs has been reported to increase the dry weights (yield) of wheat, spinach, radish, lettuce, and cucumber plants compared with mono-red LEDs (Goins et al., 1997; Yorio et al., 2001; Wang et al., 2009). In addition, the chlorophyll content in wheat seedlings grown under combined blue and red lights was shown to be relatively higher than that of seedlings grown under only red light (Tripathy and Brown,

Table 1. Growth characteristics of cherry tomato seedlings nursed under various combined ratios of red and blue LEDs at 27 days of treatment $(n=4)$.

\begin{tabular}{ccccccccc}
\hline \hline \multirow{2}{*}{ Treatment } & \multicolumn{2}{c}{ Fresh weight (g/plant) } & \multicolumn{2}{c}{ Dry weight (g/plant) } & & $\begin{array}{c}\text { Leaf area } \\
\left(\mathrm{cm}^{2}\right)\end{array}$ & $\begin{array}{c}\text { Specific leaf weight } \\
\left(\mathrm{mg} \cdot \mathrm{cm}^{-2}\right)\end{array}$ & SPAD value \\
\cline { 2 - 5 } & Shoot & Root & Shoot & Root & & & \\
\hline Control & $\mathrm{z}$ & $6.95 \mathrm{~b}^{\mathrm{y}}$ & $0.83 \mathrm{~b}$ & $0.72 \mathrm{c}$ & $0.06 \mathrm{c}$ & $229.42 \mathrm{~d}$ & $1.22 \mathrm{~b}$ & $24.63 \mathrm{~d}$ \\
100R:0B & $7.94 \mathrm{~b}$ & $1.33 \mathrm{a}$ & $0.78 \mathrm{bc}$ & $0.12 \mathrm{a}$ & $271.55 \mathrm{bcd}$ & $1.86 \mathrm{a}$ & $30.83 \mathrm{bc}$ \\
87R:13B & $13.94 \mathrm{a}$ & $1.32 \mathrm{a}$ & $0.91 \mathrm{abc}$ & $0.11 \mathrm{ab}$ & $340.92 \mathrm{ab}$ & $0.88 \mathrm{c}$ & $31.77 \mathrm{~b}$ \\
74R:26B & $12.86 \mathrm{a}$ & $0.89 \mathrm{~b}$ & $1.16 \mathrm{a}$ & $0.07 \mathrm{c}$ & $322.68 \mathrm{abc}$ & $1.09 \mathrm{bc}$ & $32.95 \mathrm{ab}$ \\
65R:35B & $12.15 \mathrm{a}$ & $1.37 \mathrm{a}$ & $1.22 \mathrm{a}$ & $0.14 \mathrm{a}$ & $347.67 \mathrm{a}$ & $1.07 \mathrm{bc}$ & $36.13 \mathrm{a}$ \\
53R:47B & $11.11 \mathrm{a}$ & $0.97 \mathrm{~b}$ & $1.13 \mathrm{ab}$ & $0.09 \mathrm{bc}$ & $300.04 \mathrm{abc}$ & $1.10 \mathrm{bc}$ & $33.37 \mathrm{ab}$ \\
41R:59B & $6.61 \mathrm{~b}$ & $0.92 \mathrm{~b}$ & $0.56 \mathrm{c}$ & $0.07 \mathrm{c}$ & $252.68 \mathrm{~cd}$ & $1.13 \mathrm{bc}$ & $27.67 \mathrm{~cd}$ \\
\hline Significance & $* * *$ & $* * *$ & $* *$ & $* * *$ & $* *$ & $* * *$ & $* * *$ \\
\hline
\end{tabular}

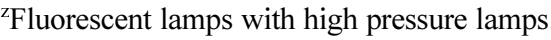

${ }^{\mathrm{y}}$ Mean separation within column's by Duncan's multiple range test.

${ }^{\mathrm{x}}$ Significant at $p<0.05(*), 0.01(* *)$ or $0.001(* * *)$. 
1995). In the study of Son and Oh (2013) that analyzed the effect of ratios of red to blue LEDs on lettuce growth, the authors obtained results similar to those of the present study. They demonstrated that an excessively high ratio of blue light (59\%) inhibited growth, and that an increasing ratio of blue LEDs resulted in a gradual decrease in fresh and dry weights and leaf area. In the study, lettuce irradiated with $0 \mathrm{~B}(100 \%$ of red light) showed the highest fresh weight, although the leaf shape was atypical, whereas tomato seedlings under the same treatment showed signifi- cantly inhibited growth. This can be explained by differences in the responses of different plant species and cultivars to light quality, which has been reviewed in LEDrelated studies (Gupta and Jatoth, 2013). Compared with the control (FL), most of the combined red and blue LED treatments used in this study (i.e., RB treatment with $53 \% \sim 87 \%$ red light) enhanced the growth of tomato, demonstrating the potential use of LEDs for the production of tomato seedlings.

For parameters related to the stem of cherry tomato seed-
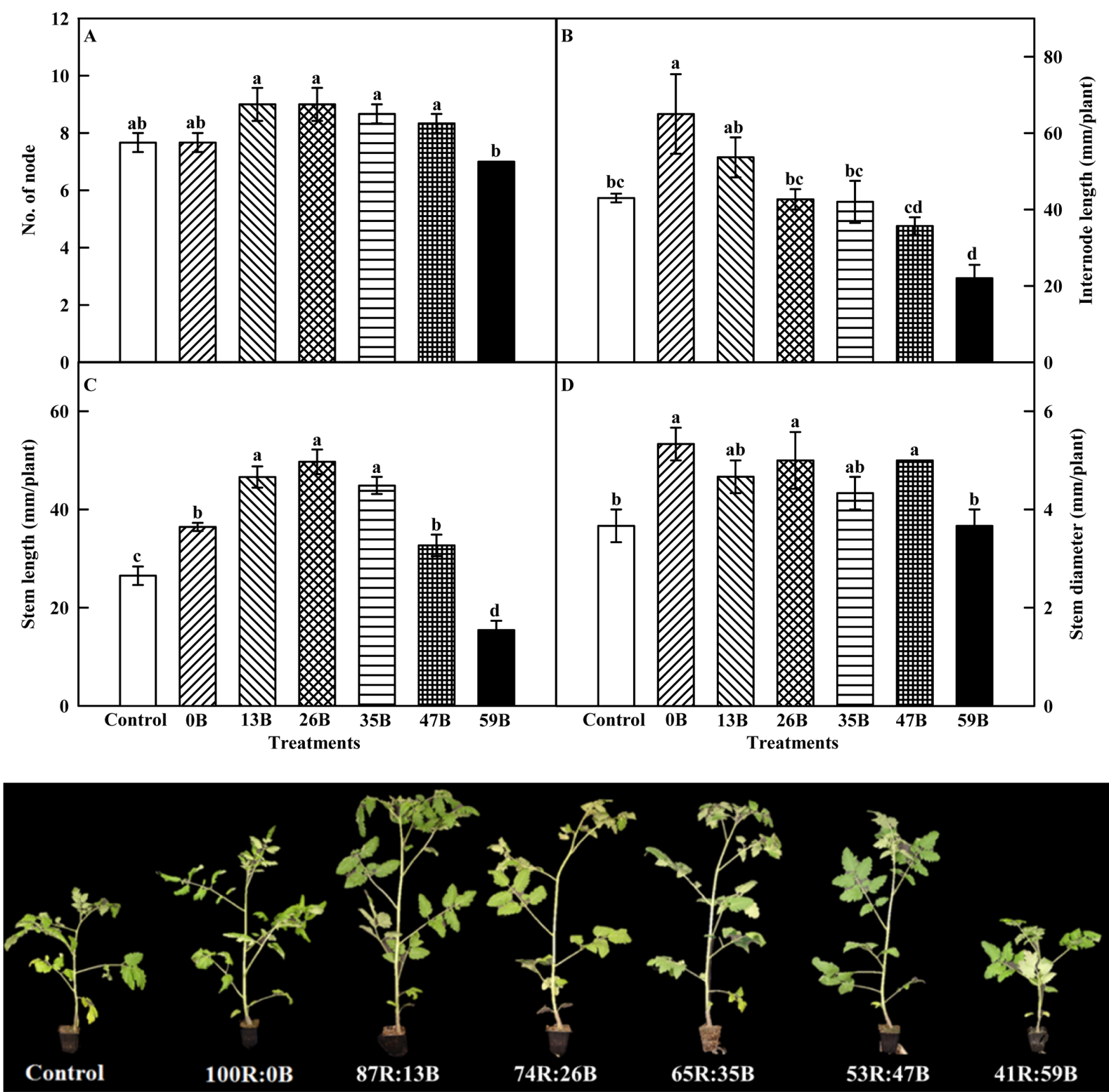

Fig. 2. Number of node (A), internode length (B), stem length (C), stem diameter (D) of cherry tomato seedlings grown under various combined ratios of red to blue LEDs and a picture of cherry tomato seedlings at 27 days of LED treatment (E) $(p<0.05)$. 
lings (Fig. 2), the number of nodes after 27 days of LED treatment was highest in the $13 \mathrm{~B}$ and $26 \mathrm{~B}$ treatments, although the values were not significantly different from those obtained for the control and other treatments, with the exception of 59B (Fig. 2A). The internode length between the second and third nodes was shown to decrease with a gradual increase in the ratio of blue light (Fig. 2B). The stem length was significantly higher in the $13 \mathrm{~B}, 26 \mathrm{~B}$, and $35 \mathrm{~B}$ treatments, followed by $0 \mathrm{~B}, 47 \mathrm{~B}$, the control, and 59B (Fig. 2C). Treatment 26B resulted in the longest stem length, which was approximately 3.2 times longer than that obtained with the 59B treatment that yielded the shortest length. No significant difference in stem diameter was detected among the combined red and blue LED treatments, although stem diameters in most of the LED treatments, such as $0 \mathrm{~B}, 26 \mathrm{~B}$, and $47 \mathrm{~B}$, were higher than those in the control or 59B treatments (Fig. 2D).

Generally, red light is known to promote the length of hypocotyl and plant height, whereas blue light is known to have the opposite effect (Whitelam and Halliday, 2007; Johkan et al., 2010). This is consistent with a previous study where a higher ratio of blue to red light was shown to decrease tomato plant height (Nanya et al., 2012). However, in our previous study using monochromatic light, 'Cuty' cherry tomato seedlings grown under blue light showed 1.9 times longer stems than those grown under red light (Kim et al., 2014). This finding suggests that plant responses to light quality may mainly be dependent on plant species (Buso and Bliss, 1988). According to the result of our previous study (Kim et al., 2014), the 59B treatments, which has the highest ratio of blue light, should have promoted the greatest plant height. In contrast, however, we found that an increase in the ratio of blue light over 26B resulted in a decrease in plant height (Fig. 2C and 2E). This suggests that the stem length of cherry tomato may be sensitive to a specific ratio of red to blue light rather than to the quantity of red or blue lights in combined red and blue LED treatments (Fig. 2C). When tomato and cucumber seedlings were irradiated under a 1:1 ratio of red to blue LEDs, the stem length was observed to be more inhibited than that in the control (FL) (Um et al., 2009; Liu et al., 2012), which is consistent with the results of the present study (Fig. 2C). Moreover, Nanya et al. (2012) also observed a greater stem length in tomato seedlings subjected to a low blue ratio (10B:90R) treatment compared with those exposed to a high blue ratio (50B:50R). Crypto- chrome photoreceptors are known to be blue light (390$480 \mathrm{~nm}$ ) receptors and when stimulated inhibit hypocotyl elongation (Ahmad and Cashmore, 1996). Accordingly, the inhibition in stem length by blue LEDs is assumed to be attributed to the stimulation of cryptochromes (Fig. 2C). Regardless of internode length (Fig. 2B), the stem length (Fig. 2C) was longest under $13 \% \sim 35 \%$ of blue light, which appeared to be due to the rapid growth of internodes after the third node.

\subsection{Post-transplantation}

At 37 DAT, the growth of tomato plants was observed to be affected by the different RB LED treatments to which seedlings were exposed for 27 days prior to transplantation (Table 2). Although there was no significant difference among treatments with regards to shoot fresh and dry weights, the plants treated with LEDs still maintained higher values than the control. With regards to leaf area, plants subjected to the 47B and 59B treatments, which had a high ratio of blue light, showed a significant increase compared with the control. The chlorophyll content and stem diameter of the transplanted plants also showed no significant differences between LED treatments and the control, whereas the number of nodes was significantly highest in the $26 \mathrm{~B}$ and $47 \mathrm{~B}$ treatments, and lowest in the 59B and control treatments. Plant height showed a trend similar to node number, with the $26 \mathrm{~B}$ treated plants being significantly higher than those in the control and 59B treatments.

In studies similar that reported here, the dry and fresh weights of paprika, cucumber, and tomato after transplanting and raised under various types of LEDs showed no significant differences in closed-type plant production systems (Um et al., 2009; Lee et al., 2012), which is consistent with the results of this study with respect to shoot fresh and dry weights and stem diameter (Table 2). Fan et al. (2013) revealed that the leaf development (mesophyll tissue, palisade cells, and spongy cells) of tomato seedlings is attenuated when the PPFD is below $300 \mu \mathrm{mol} \cdot \mathrm{m}^{-2} \cdot \mathrm{s}^{-1}$. In the present study, during the seedling stage wherein leaf development is affected, the PPFD was only approximately $200 \mu \mathrm{mol} \cdot \mathrm{m}^{-2} \cdot \mathrm{s}^{-1}$ before transplanting. Accordingly, the PPFD used in the present study was probably lower than that necessary for normal plant biomass accumulation (O'Carrigan et al., 2014), and therefore this might have had less effect on the tomato plants after transplanting. More- 
Growth and Development of Cherry Tomato Seedlings Grown under Various Combined Ratios of Red to Blue LED Lights and Fruit...

Table 2. Growth characteristics of cherry tomato plants nursed under various combined ratios of red and blue LEDs at 37 days after transplanting $(n=3)$.

\begin{tabular}{|c|c|c|c|c|c|c|c|}
\hline \multirow{2}{*}{ Treatment } & \multicolumn{2}{|c|}{ Shoot (g/plant) } & \multirow{2}{*}{ Leaf area $\left(\mathrm{m}^{2}\right)$} & \multirow{2}{*}{ SPAD value } & \multirow{2}{*}{$\begin{array}{l}\text { Stem diameter } \\
(\mathrm{mm})\end{array}$} & \multirow{2}{*}{ No. of node } & \multirow{2}{*}{$\begin{array}{l}\text { Plant height } \\
\text { (cm/plant) }\end{array}$} \\
\hline & Fresh weight & Dry weight & & & & & \\
\hline Control $^{\mathrm{z}}$ & 502.73 & 62.67 & $0.48 \mathrm{c}^{\mathrm{y}}$ & 54.67 & 1.03 & $19.67 \mathrm{bc}$ & $107.67 \mathrm{bc}$ \\
\hline 100R:0B & 607.07 & 72.17 & $0.60 \mathrm{bc}$ & 56.70 & 0.93 & $22.00 \mathrm{ab}$ & $130.67 \mathrm{ab}$ \\
\hline 87R:13B & 533.53 & 66.87 & $0.48 \mathrm{c}$ & 51.93 & 0.80 & $21.67 \mathrm{ab}$ & $123.67 \mathrm{ab}$ \\
\hline 74R:26B & 585.23 & 69.90 & $0.65 \mathrm{abc}$ & 53.77 & 0.90 & $24.00 \mathrm{a}$ & $141.00 \mathrm{a}$ \\
\hline $65 \mathrm{R}: 35 \mathrm{~B}$ & 585.70 & 69.60 & $0.61 \mathrm{abc}$ & 53.60 & 0.93 & $18.00 \mathrm{c}$ & $118.33 \mathrm{ab}$ \\
\hline 53R:47B & 604.77 & 68.53 & $0.87 \mathrm{a}$ & 54.63 & 1.00 & $23.33 \mathrm{a}$ & $131.33 \mathrm{ab}$ \\
\hline 41R:59B & 611.20 & 67.87 & $0.79 \mathrm{ab}$ & 51.33 & 1.17 & $19.00 \mathrm{c}$ & $93.33 \mathrm{c}$ \\
\hline Significance $^{\mathrm{x}}$ & NS & NS & $*$ & NS & NS & $* * *$ & $* *$ \\
\hline
\end{tabular}

${ }^{\mathrm{z}}$ Fluorescent lamps with high pressure lamps.

${ }^{\mathrm{y}}$ Mean separation within column's by Duncan's multiple range test.

${ }^{\mathrm{x}} \mathrm{NS}=$ nonsignificant, ${ }^{*},{ }^{* *},{ }^{* *}$ Significant at $p<0.05,0.01$ or 0.001 , respectively.

Table 3. Fruit yield and quality of cherry tomato nursed under various combined ratios of red and blue LEDs after transplanting $(n=6)$.

\begin{tabular}{cccccc}
\hline \hline Treatment & $\begin{array}{c}\text { Total fruit yield } \\
\text { (kg/plant) }\end{array}$ & $\begin{array}{c}\text { Fruit weight } \\
\text { (g/fruit) }\end{array}$ & $\begin{array}{c}\text { Fruit size } \\
(\mathrm{mm} / \text { fruit })\end{array}$ & $\begin{array}{c}\text { Soluble solids content } \\
\left({ }^{\circ} \text { Brix }\right)\end{array}$ & $\begin{array}{c}\text { Total acidity } \\
(\%)\end{array}$ \\
\hline Control $^{\mathrm{z}}$ & $1.14 \mathrm{~cd}^{\mathrm{y}}$ & $28.93 \mathrm{abc}$ & $39.08 \mathrm{a}$ & 6.83 & 0.93 \\
100R:0B & $1.33 \mathrm{bcd}$ & $25.32 \mathrm{~d}$ & $37.33 \mathrm{ab}$ & 6.88 & 0.79 \\
87R:13B & $1.62 \mathrm{ab}$ & $27.65 \mathrm{bcd}$ & $38.67 \mathrm{a}$ & 7.13 & 1.13 \\
74R:26B & $1.77 \mathrm{a}$ & $27.63 \mathrm{bcd}$ & $36.42 \mathrm{~b}$ & 7.50 & 1.03 \\
65R:35B & $1.62 \mathrm{ab}$ & $31.24 \mathrm{a}$ & $39.00 \mathrm{a}$ & 6.87 & 0.80 \\
53R:47B & $1.41 \mathrm{abc}$ & $26.88 \mathrm{~cd}$ & $37.17 \mathrm{ab}$ & 7.05 & 0.89 \\
41R:59B & $0.98 \mathrm{~d}$ & $29.57 \mathrm{ab}$ & $38.83 \mathrm{a}$ & 6.83 & 0.90 \\
\hline Significance $^{\mathrm{x}}$ & $* *$ & $* *$ & $*$ & $\mathrm{NS}$ & $\mathrm{NS}$
\end{tabular}

${ }^{\mathrm{z}}$ Fluorescent lamps with high pressure lamps.

${ }^{y}$ Mean separation within column's by Duncan's multiple range test.

${ }^{\mathrm{x}} \mathrm{NS}=$ nonsignificant, ${ }^{*},{ }^{*}$ Significant at $p<0.05$ or 0.01 , respectively.

over, this could be attributed to adaptation to greenhouse conditions, which are less controlled than those of growth chambers, after transplanting, as a consequence of the disappearance of characteristics before transplanting (Johkan et al., 2010). However, the differences in growth characteristics, such as leaf area, number of nodes, and plant height growth, before transplanting were maintained to some extent at 37 DAT. Thus, our results show that, in the case of tomato, the control of environmental factors, including light, for plant growth before transplanting may be one of the strategies for improving plant growth and yield after transplanting.

\section{Fruit yield and quality}

Fruit yield was affected by the growth characteristics of tomato seedlings before transplanting (Table 3). The total fruit yields obtained in treatments $13 \mathrm{~B}, 26 \mathrm{~B}$, and $35 \mathrm{~B}$ were significantly higher than that of the control. In the case of the 26B treatment, the yield was approximately 1.6 times higher than that of the control and 1.8 times higher than that of the 59B treatment, which had the lowest fruit yield among all treatments. The mean fruit weight was highest in the $35 \mathrm{~B}$ treatment and lowest in $0 \mathrm{~B}$, whereas fruit size was lowest in $26 \mathrm{~B}(36.42 \mathrm{~mm})$, which was $6.8 \%$ less than that in the control $(39.08 \mathrm{~mm})$. Soluble solids content and total acidity, which are indicative of tomato fruit quality, were not significantly different between the control and all LED treatments.

The increased fruit yield obtained in several RB treatments, including 26B, may be closely associated with the 
relatively greater plant height and larger number of nodes before transplanting (Table 2), compared with the other treatments and the control. Previous studies have reported no significant difference in the yields of tomato, cucumber, paprika, and lettuce grown under combined red and blue LEDs, monochromatic red or blue LEDs, or fluorescent lamps (Johkan et al., 2010; Lee et al., 2012; Um et al., 2009), which is inconsistent with the results of the present study. These contrasting results may be attributed to differences in the PPFD, duration, light periods, and light quality of LEDs. The lack of significant differences in soluble solids content and total acidity in cherry tomatoes is, however, consistent with the results of Johkan et al. (2010), who observed no significant differences in the quality parameters of lettuce after transplanting.

Light quality plays a crucial role in the yield (growth) and quality of crops. In this study, we examined the effects of various ratios of red to blue LEDs, which are common artificial light conditions in closed-type plant production systems, on the growth characteristics of cherry tomato seedlings and the yield and quality of cherry tomatoes after transplanting. RB combinations with $13 \% \sim 47 \%$ blue LEDs have a positive influence on growth characteristics such as shoot fresh and dry weights and plant height of cherry tomato seedlings compared with the control (fluorescent lamps). The improved growth of the seedlings was maintained after transplanting and resulted in an enhancement of cherry tomato fruit yield. These results provide valuable information for lighting conditions in the production of cherry tomato seedlings in closed-type plant production systems.

\section{Acknowledgement}

This work was financially supported by the Research Year of Chungbuk National University in 2017.

\section{Literature cited}

Ahmad, M. and A.R. Cashmore. 1996. Seeing blue: the discovery of cryptochrome. Plant Mol. Biol. 30:851-861.

Brown, C.S., A.C. Shuerger, and J.C. Sager. 1995. Growth and photomorphogenesis of pepper plants under red light-emitting diodes with supplemental blue or far-red lighting. J. Amer. Soc. Hort. Sci. 120:808-813.

Buso, G.S.C. and F.A. Bliss. 1988. Variability among lettuce cultivars grown at two levels of available phosphorus. Plant Soil 111:67-73.
Buwalda, F., E.J. van Henten, A. de Gelder, J. Bontsema, and J. Hemming. 2006. Toward an optimal control strategy for sweet pepper cultivation. 1. A dynamic crop model. Acta Hort. 718:391-398.

Fan, X.X., Z.G. Xu, X.Y. Liu, C.M. Tang, L.W. Wang, and X.L. Han. 2013. Effects of light intensity on the growth and leaf development of young tomato plants grown under a combination of red and blue light. Sci. Hortic. 153:50-55.

Garcia-Closas, R., A. Berenguer, M.J. Tormo, M.J. Sanchez, J.R. Quiros, C. Navarro, R. Amaud, M. Dorronsoro, M.D. Chirlaque, A. Barricarte, E. Ardanaz, P. Amiano, C. Martinez, A. Agudo, and C.A. Gonzalez. 2004. Dietary sources of vitamin $\mathrm{C}$, vitamin $\mathrm{E}$, and specific carotenoids in Spain. Brit. J. Nutr. 91:1005-1011.

Goins, G.D., N.C. Yorio, M.M. Sanwo, and C.S. Brown. 1997. Photomorphogenesis, photosynthesis, and seed yield of wheat plants grown under red light-emitting diodes (LEDs) with and without supplemental blue lighting. J. Exp. Bot. 48:1407-1413.

Gupta, S.D. and B. Jatothu. 2013. Fundamentals and applications of light-emitting diodes (LEDs) in in vitro plant growth and morphogenesis. Plant Biotechnol. Rep. 7:211220.

Hernández, R. and C. Kubota. 2016. Physiological responses of cucumber seedlings under different blue and red photon flux ratios using LEDs. Environ. Exp. Bot. 121:66-74.

Hopkins, W.G. and N.P.A. Huner. 2004. Introduction to plant physiology. 3rd Ed. John Wiley and Sons, Hoboken, NJ., USA.

Johkan, M., K. Shoji, F. Goto, S. Hashida, and T. Yoshihara. 2010. Blue light-emitting diode light irradiation of seedlings improves seedling quality and growth after transplanting in red leaf lettuce. HortScience 45:1809-1814.

Kim, E.Y., S.A. Park, B.J. Park, Y. Lee, and M.M. Oh. 2014. Growth and antioxidant phenolic compounds in cherry tomato seedlings grown under monochromatic light-emitting diodes. Hort. Environ. Biotechnol. 55:506-513.

Kozai T. 2013. Sustainable plant factory: Closed plant production systems with artificial light for high resource use efficiencies and quality produce. Acta Hort. 1004:27-40.

Lee, J.S., H.I. Lee, and Y.H. Kim. 2012. Seedling quality and early yield after transplanting of paprika nursed under lightemitting diodes, fluorescent lamps and natural light. J. BioEnviron. Control 21:220-227.

Li, Y., G. Xin, M. Wei, Q. Shi, F. Yang, and X. Wang. 2017. Carbohydrate accumulation and sucrose metabolism responses in tomato seedling leaves when subjected to different light qualities. Sci. Hortic. 225: 490-497.

Liu, X.Y., S.R. Guo, T.T. Chang, Z.G. Xu, and T. Takafumi. 2012. Regulation of the growth and photosynthesis of cherry tomato seedlings by different light irradiations of light emitting diodes (LED). Afri. J. Biotechnol. 11:61696177. 
Growth and Development of Cherry Tomato Seedlings Grown under Various Combined Ratios of Red to Blue LED Lights and Fruit...

Massa, G.D., H.H Kim, R.M. Wheeler, and C.A. Mitchell. 2008. Plant productivity in response to LED lighting. HortScience 43:1951-2008.

McNellis, T.W. and X.W. Deng. 1995. Light control of seedling morphogenetic pattern. J. Plant Cell 7:1749-1761.

Matsuda, R., K. Ohashi-Kaneko, K. Fujiwara, E. Goto, and K. Kurata. 2004. Photosynthetic characteristics of rice leaves grown under red light with or without supplemental blue light. Plant Cell Physiol. 45:1870-1874.

Nanya, K., Y. Ishigami, S. Hikosaka, and E. Goto. 2012. Effects of blue and red light on stem elongation and flowering of tomato seedlings. Acta Hortic. 956:264-266.

O'Carrigan, A, E. Hinde, N. Lu, X. Xu, H. Duan, G. Huang, M. Mak, B. Bellotti, and Z. Chen. 2014. Effects of light irradiance on stomatal regulation and growth of tomato. Environ. Exp. Bot. 98:65-73.

Oh, S.I. 2012. Characteristics and reduction of berry cracking in 'Heukgoosul' and 'Tamnara' grapes (Vitis labruscana B.). PhD. Diss., Univ. of Chungbuk, Cheongju, Korea

Rehman, M., S. Ullah, Y. Bao, B. Wang, D. Peng, and L. Liu. 2017. Light-emitting diodes: whether an efficient source of light for indoor plants? Environ. Sci. Pollut. Res. 1-10.

Riso, P., F. Visioli, G. Testolin, and M. Porrini. 2004. Lycopene and vitamin $\mathrm{C}$ concentrations increase in plasma and lymphocytes after tomato intake. Effects on cellular antioxidant protection. Eur. J. Clinical Nutr. 58:350-1358.

Rural Development Adminstration (RDA). 2001. Tomato culture (Standard textbook for farming-106). RDA press, Suwon, Korea

Son, K.H. and M.M. Oh. 2013. Leaf shape, growth, and anti- oxidant phenolic compounds of two lettuce cultivars grown under various combinations of blue and red light-emitting diodes. HortScience 48:988-995.

Terashima, I., T. Fujita, T. Inoue, W.S. Chow, and R. Ohuchi. 2009. Green light drives leaf photosynthesis more efficiently than red light in strong white light: revisiting the enigmatic question of why leaves are green. J. Plant Cell Physiol. 50:684-697.

Tripathy, B.C. and C.S. Brown. 1995. Root-shoot interaction in the greening of wheat seedlings grown under red light. Plant Physiol. 107:407-411.

Um, Y.C., S.S. Oh, J.G. Lee, S.Y. Kim, and Y.A. Jang. 2010. The development of container-type plant factory and growth of leafy vegetables as affected by different light sources. J. Bio-Environ. Control 19:333-342.

Um, Y.C., Y.A. Jang, J.G. Lee, S.Y. Kim, S.R. Cheong, S.S. Oh, S.H. Cha, and S.C. Hong. 2009. Effects of selective light sources on seedling quality of tomato and cucumber in closed nursery system. J. Bio-Environ. Control 18:370-376.

Wang, H., M. Gu, J. Cui, K. Shi, T. Zhou, and J. Yu. 2009. Effects of light quality on $\mathrm{CO}_{2}$ assimilation, chlorophyll-fluorescence quenching, expression of Calvin cycle genes and carbohydrate accumulation in Cucumis sativus. J. Photochem. Photobiol. B. 96:30-37.

Whitelam, G. and K. Halliday. 2007. Light and plant development. Blackwell Publishing, Oxford, UK.

Yorio, N.C., G.D. Goins, H.R. Kagie, R.M. Wheeler, and J.C. Sager. 2001. Improving spinach, radish and lettuce growth under red light-emitting diodes (LEDs) with blue light supplementation. HortScience 36:380-383. 


\section{다양한 조합의 적색과 청색 혼합 LED광에서 자란 방울 토마토 묘의 생육과 정식 후 수확량 및 품질 \\ 손기호 ${ }^{1,2} \cdot$ 김은영 ${ }^{3} \cdot$ 오명민 ${ }^{1,2 *}$ \\ 1충북대학교 축산·원예.식품공학부 원예학전공 \\ ${ }^{2} \mathrm{BK} 21$ 생물건강소재산업화사업단 \\ 3영동군 농업기술센터}

적 요. 적색과 청색광은 식물의 광합성에 효과적인 파장으로 알려져 있다. 본 연구는 다양한 조합의 적색과 청색 LED 혼합광에서 자란 방울 토마토 묘의 생장과 정식 후의 생산량과 품질에 대한 영향을 구명하였다. 파 종 후 2주된 방울 토마토 묘(Solanum lycopersicum L. cv. 'Cuty')를 적색 $(655 \mathrm{~nm})$ 과 청색 $(456 \mathrm{~nm}) \mathrm{LED}$ 의 다양 한 비율의 혼합광 [red:blue = 41:59 (59B), 53:47 (47B), 65:35 (35B), 74:26 (26B), 87:13 (13B), or 100:0 (0B)과 형광등(대조구)이 설치된 생장상에 옮겨준 후 $25 / 20^{\circ} \mathrm{C}$ (주/야), 광합성 광량자속 $198.6 \pm 5 \mu \mathrm{mol} \cdot \mathrm{m}^{-2} \cdot \mathrm{s}^{-1}$ (12시간)의 조건에서 27 일간 육묘하였다. 그 후 방울 토마토를 벤로형 온실에 정식하여 75 일동안 재배하였다. 정식 전 육묘 단계에서 27 일간 $\mathrm{LED}$ 처리된 $0 \mathrm{~B}$ 와 $59 \mathrm{~B}$ 처리구를 제외한 모든 $\mathrm{RB}$ 혼합광 처리의 지상부 생 체중이 대조구에 비해 높았다. 지상부 건물중과 엽면적 또한 지상부 생체중과 유사한 경향을 보였다. 줄기 신

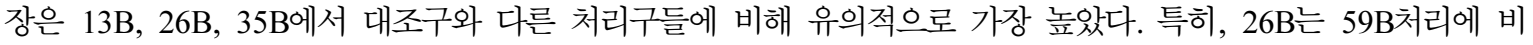
해 약 3.2 배 높은 줄기 신장을 보였다. 정식 후 37 일 째에 마딧수는 $26 \mathrm{~B}$ 와 $47 \mathrm{~B}$ 에서 유의적으로 가장 높았고, 식물 초장은 $26 \mathrm{~B}$ 에서 대조구와 $59 \mathrm{~B}$ 에 비해 유의적으로 높았다. 가장 높은 총 과실 생산량을 보였던 $26 \mathrm{~B}$ 는 대조구에 비해 1.6 배, $59 \mathrm{~B}$ 에 비해 1.8 배 높은 총 과실 생산량을 보였다. 따라서, 본 연구는 적색과 청색 LED 의 다양한 혼합 비율이 방울 토마토 묘의 생장 및 발달과 정식 후의 과실 생산량과 같은 생식생장에 영향에 중요한 요소임을 제시한다.

추가주제어 : 과실품질, 마딧수, 초장, 줄기신장, 총 과실량 